CAMTBRIDGE: PRINTED BY

W. LEWIS, M.A.

AT THE UNIVERSITY PRESS 


\title{
MEETINGS FOR 1927-28
}

\author{
Michaelmas Termi, 1927
}

1. Thursday, October 27, at 4.15

2. Thursday, November 10 , at 4.15

3. Thursday, November 24 , at 4.15

\section{Lent Term, 1928}

1. (Amual Meeting) Thursday, January 19, at 4.15

$\therefore$. Thursday, February 9, at 4.15

3. Thursday, Hebruary 23 , at 4.15

$$
\text { EAster Term, } 1928
$$

i. Thursday, May 3 , at 4.45

In the Michatelmas Term, 1927, the Society will meet in Proî. Adcock's Rooras, King's College; in the Lent Term, 1928, in the Benson Hall, Magdalene College; in the Easter Term, 1928, in Mr A. H. Lloyd's House, St John's House, Grange Road.

Members wishing to communicate papers or points for discussion are requested to inform one of the Secretaries.

The Society's Library is in the Nuseum of Classical Archaeology, Little St Mary's Lane. 


\section{Cambringe झytlologítal Soctetp.}

The object of the Society is the promotion and publication of researches into the Indo-European languages and literatures, and the promotion of Philological studies in general.

Ail Studeuts of Philology are eligible as members.

The subscription is $£ 1.1$ s. annually, or $£ 10.10$ s. life composition.

Subscribers receive the Classical Quarterly and all the publications of the Society, including the Proceedings and Transactions. Members of the Society who wish to complete their sets of the Journal of Philology can now obtain back volumes at half price (excepting Vols. II, V, VIII to XII and XIV which are nearly out of print) by applying directly to the publishers, Messrs Macmillan \& Co. Ltd., St Martin Street, London.

Those who wish to join are asked to communicate with one of the Secretaries, who will give further information.

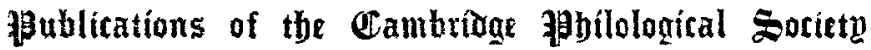
sínce 1880.

Transactions, Vol. I (1872-1880)

s. $d$.

Transactiosis, Vol. II $(1881,18 \overline{2} 2)$, with Index to

Volumes I and II (and Proceedings for 1882) ...

Traysactions, Vol. III (1886-1893) Part I 3s. 6d.; Port I1

2s.; Part IIT 2s. 6d.; Part IV 1s. 6d.; Part $\Gamma$ with

Index

Tranactions, Vol. IV (1894-1899) Part I 3s. 6l.; Part II

Transacrions, Vol. V Parts I and II, each ... ... ...

Transactions, Vol. V Part III 2s.; Part IV ... ...

Transactirs, Vol. F Part $T$

Transactioss, Vol. VI Part I

Transactrons, Vol. VI Part II

Traxsactions, Yol. VI Part III

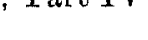

10

10

60

30

10

16

20

Procempisus, 1882 to 1888 (except Parts I, II and IV_-VI,

which are out of print), each $\ldots \quad \ldots \quad \ldots \quad \ldots$

Proceedixas, 1889 to 1926 (with Laws and List of Members), each

Speluivg Reform and Exglish Literatere by H. Sweet (out of print).

Pronunciation of Latin in the Augustax Period (Third Thousand)

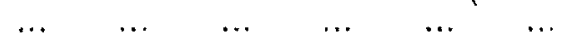

